\title{
Salt content of processed foods in the Islamic Republic of Iran, and compliance with salt standards
}

Fatemeh Zendeboodi, ${ }_{1}$ Sara Sohrabvandi, ${ }_{1}^{1}$ Elham Khanniri, ${ }_{1}^{1}$ Parang Nikmaram, ${ }^{2}$ Rozita Fanood, ${ }^{1}$ Kianoush Khosravi, ${ }^{1}$ Amir Mortazavian, ${ }^{1}$ Mohammad Gholian $^{3}$ and Nasim Khorshidian ${ }^{1}$

${ }^{1}$ Department of Food Science and Technology, Faculty of Nutrition Sciences and Food Technology, National Nutrition and Food Technology Research Institute, Shahid Beheshti University of Medical Sciences, Tehran, Islamic Republic of Iran. ${ }^{2}$ Department of Food Science and Technology, Faculty of Agricultural Engineering and Technology, Agriculture and Natural Resources, University of Tehran, Tehran, Islamic Republic of Iran. ${ }^{3}$ Grape Processing and Preservation Department, Research Institute for Grapes and Raisin, Malayer University, Malayer, Islamic Republic of Iran. (Correspondence to: Sara Soharbvandi and Elaham Khanniri: Sohrabv@sbmu.ac.ir and e.khanniri@sbmu.ac.ir).

\begin{abstract}
Background: The World Health Organization recommends a maximum daily salt intake of $5 \mathrm{~g}$ for adults; the Islamic Republic of Iran has national standards for salt content of foods.

Aims: This study aimed to determine the salt content of industrial (made in large-scale food companies) and non-industrial (made in local stores using traditional methods) foods in Tehran province and compare it with the Iranian national standards.

Methods: We determined the salt content of 555 industrial and non-industrial products from parts of Tehran province in 2016 and 2018. The types of foods examined were: canned vegetables, industrial and non-industrial pickled vegetables, industrial and non-industrial tomato paste/tomato sauce, industrial and non-industrial nuts, and non-industrial barberry juice. The salt content of each product and its compliance with Iranian national standards was evaluated.

Results: The salt content of industrial tomato paste/sauce in $2016(2.05 \mathrm{~g} / 100 \mathrm{~g})$ and non-industrial tomato paste/sauce in $2018(2.37 \mathrm{~g} / 100 \mathrm{~g})$ was higher than the Iranian standard $(1.5 / 2.0 \mathrm{~g} / 100 \mathrm{~g})$. The mean salt content of both industrial $(1.97 \mathrm{~g} / 100 \mathrm{~g})$ and non-industrial $(2.16 \mathrm{~g} / 100 \mathrm{~g})$ nuts was higher than the Iranian standard $(1.88 \mathrm{~g} / 100 \mathrm{~g})$, as was the mean salt content of non-industrial juice ( $0.79 \mathrm{~g} / 100 \mathrm{~mL}$ versus $0.25 \mathrm{~g} / 100 \mathrm{~mL}$ ). In 2018 , only $48 \%$ and $40 \%$ of industrial and nonindustrial tomato pastes/sauces met the Iranian standard. Overall, industrial products conformed better with the national standard than non-industrial products.
\end{abstract}

Conclusions: Efforts are needed to reduce the salt content of processed food in the Islamic Republic of Iran and ensure they meet the Iranian standards.

Keywords: salt, dietary sodium chloride, food products, Iran.

Citation: Zendeboodi F; Sohrabvandi S; Khanniri E; Nikmaram P; Fanood R; Khosravi K; et al. Salt content of processed foods in the Islamic Republic of Iran, and compliance with salt standards. East Mediterr Health J. 2021;27(7):687-692. https://doi.org/10.26719/2021.27.7.687

Received: 26/07/20; accepted: 21/09/20

Copyright (c) World Health Organization (WHO) 2021. Open Access. Some rights reserved. This work is available under the CC BY-NC-SA 3.o IGO license (https://creativecommons.org/licenses/by-nc-sa/3.o/igo).

\section{Introduction}

According to the scientific literature, one of the main factors that causes chronic noncommunicable diseases (such as cardiovascular disease) is the excessive use of processed food. Production and processing of these types of foods have spread around the world (1). Salt (sodium chloride) is a component of processed food and excessive consumption of these foods results in a high intake of salt. According to extensive research, there is a direct relationship between salt consumption and blood pressure (2), and a reduction in daily salt intake of $4.4 \mathrm{~g}$ can results in lower blood pressure (3). High blood pressure is one of the main factors associated with death in adults globally. Furthermore, the risk of cardiovascular diseases increases in parallel with increases in blood pressure. In addition to its effect on blood pressure, salt can lead to other health conditions, such as kidney stones, urinary calcium excretion, disorders of bone metabolism, gastric cancer, cataracts and asthma $(2,4)$. According to the World Health
Organization (WHO) in 2018, in order to improve public health, the maximum recommended daily salt intake is $5 \mathrm{~g}$ for adults (5). Salt is a natural component of many foods such as milk, cream and eggs, but processed products, including bread, processed meat (e.g. sausages), nuts, canned and pickled products, and fermented dairy products, contain a higher concentration of salt (6). While salt poses health risks, this compound is also a vital element in biological activity and food processing, including regulating the osmotic pressure of a living cell and producing palatable food. Salt is a food preservative which increases food safety by reducing the water activity of a food. Salt also intensifies the taste and aroma of food and can enhance textural properties, alter the consistency of the food and influence food appearance and feel. Given these effects of salt on food, reducing the amount of salt in processed food can reduce food acceptability (6).

The salt consumption of Iranians is much higher than the WHO recommended amount (7). Many Iranians do not know about the health hazards of salt and the 
safe amount to consume daily, and do not have any knowledge about how much salt enters the body through consumption of processed food. Therefore, monitoring the salt content of foods that are distributed in the supermarkets is one way that can raise the awareness of society and improve public health (8). In this regard, the Iranian Ministry of Health and Medical Education established a national committee to oversee decisions and activities to monitor and reduce factors that increase the risk of noncommunicable diseases in the country and to develop new regulations in line with WHO recommendations.

Therefore, this study aimed to determine the salt content of the most commonly consumed processed foods in the Islamic Republic of Iran and evaluate the compliance of each food group with the national salt standards (9-11).

\section{Methods}

We assessed the salt content of 555 types of processed food available in Tehran province in 2016 and 2018. We categorized food products into eight groups: non-industrial fruit juices (28 products), industrial tomato paste and sauce (54 products), non-industrial tomato paste and sauce (21 products), canned vegetables (76 products), industrial pickles (88 products), non-industrial pickles (112 products), industrial processed nuts (56 products) and non-industrial processed nuts (120 products). Industrial products are those made in large-scale food companies and non-industrial products are those made in local stores using traditional methods.

The salt content of these products was evaluated according to the national standard of the Islamic Republic of $\operatorname{Iran}(9,12)$.

An ANOVA (with Duncan post hoc, repeated measures, 2018) was used to determine significant differences between each food group produced in 2016 and 2018 and to determine significant differences with the Iranian national standard.

\section{Results}

According to the Iranian national standard for canned vegetables, the permitted level of salt is $1.5-2.0 \mathrm{~g} / 100 \mathrm{~g}$ (9). The mean salt content of industrial canned vegetables was $1.1 \mathrm{~g} / 100 \mathrm{~g}$ and $1.2 \mathrm{~g} / 100 \mathrm{~g}$ in 2016 and 2018, ren spectively. In 2016, all of the samples of industrial canned vegetables complied with the Iranian national standard, while about $4 \%$ of them contained more than the standard level in 2018 (Figure 1). Based on the serving size of canned foods ( $125 \mathrm{~g}$ ), the average daily per capita ine take of salt and sodium is $1.5 \mathrm{~g}$ and $585 \mathrm{mg}$, respectively (Table 1). The statistical results presented in Table 2 show that the mean salt content of canned vegetable in 2016 and 2018 were statistically different.

The mean salt content of industrial pickles complied with the Iranian national standard in 2016, but in 2018, about $4 \%$ of industrial pickles did not (Figure 1). Based on the serving size of industrial pickles $(50 \mathrm{~g})$, the average

Figure 1 Compliance (\%) of industrial and non-industrial food products with the Iranian national standard: a) 2016 ; b) 2018
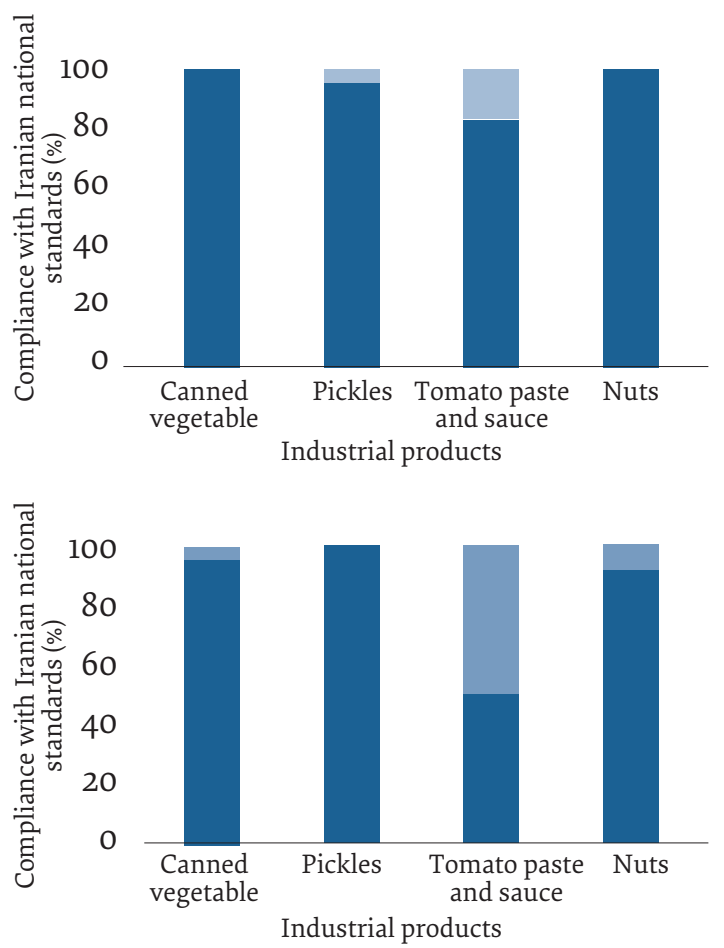
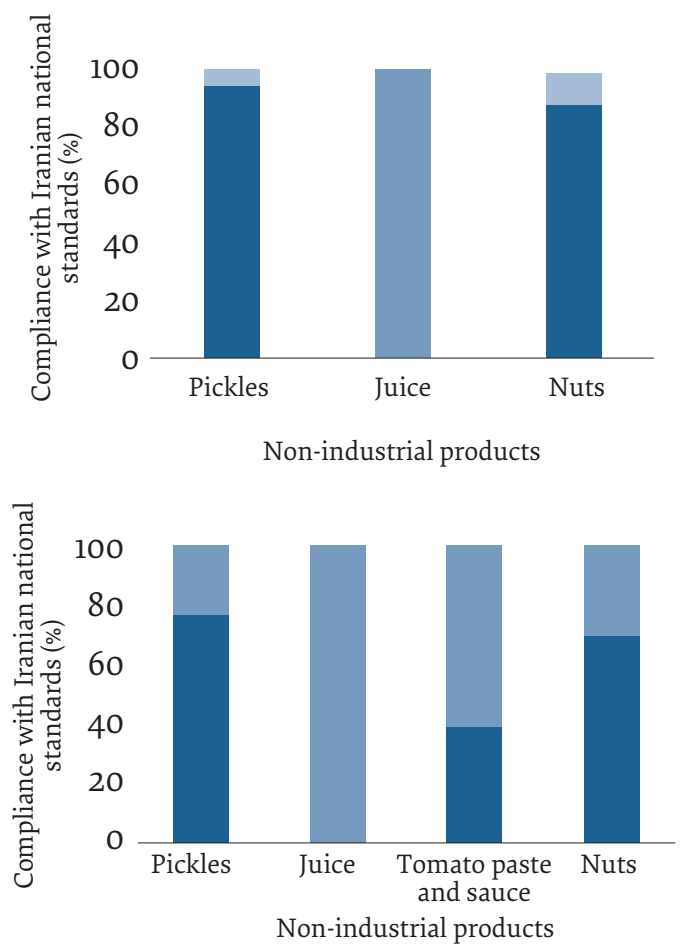

non-compliance 


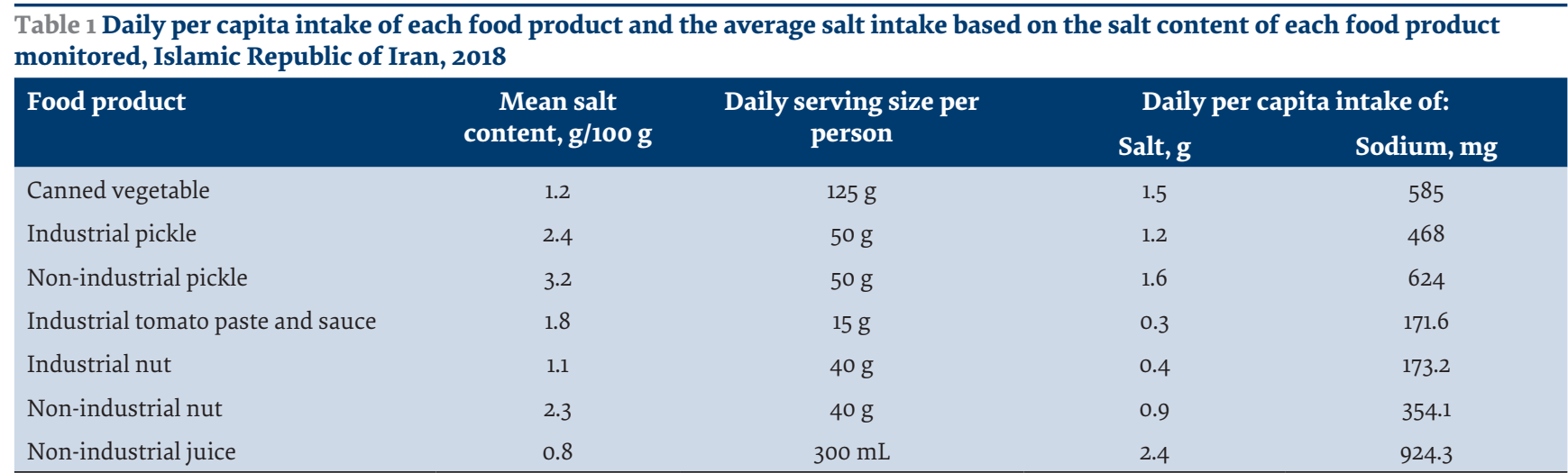

per capita intake of salt and sodium was $1.2 \mathrm{~g}$ and $468 \mathrm{mg}$, respectively (Table 1).

The compliance with the Iranian national standards for salt content of industrial tomato paste was $83 \%$ and $48 \%$ in 2016 and 2018, respectively (Figure 1). There were no significant differences between the salt content of tomato paste and sauce in 2016 and 2018 (Table 2). The standard compliance rate of non-industrial tomato sauces was $40 \%$ in 2018 , which was lower than the industrial products (Figure 1).

With regard to nuts, industrial salted sunflower seeds had the highest mean salt content of nuts while industrial salted pistachios and roasted pistachios had the lowest. However, one brand of industrial pumpkin seed had the lowest salt content, while another brand of pumpkin seed had the highest salt content. As regards non-industrial nuts and seeds, the salt content of some samples was more than the standard allowable value in 2016, including pumpkin seeds, Japanese seeds and cashew nuts. In 2018, the salt content of pumpkin seeds, Japanese seeds, sunflower seeds and watermelon seeds was more than the permitted level. The compliance of non-industrial nuts with the Iranian national standard was $88 \%$ and $72 \%$ in 2016 and 2018 , respectively.

There is no determined standard for salt content of pomegranate juice, blueberry juice, blackberry, sour cherry juice and plum juice; however, the evaluation of the salt content of barberry juice showed that it was more than permitted value, especially in 2018 .

\section{Discussion}

Our findings show that non-industrial products had a lower rate of compliance with the Iranian standards. Thus, non-industrial products are more likely to be harmful to sensitive and vulnerable people such as elderly people, children and people with high blood pressure and cardiovascular disease. The Islamic Republic of Iran is a large country with a variety of cultures and dietary behaviours. Our study determined that some food formulation should be revised to improve public health in the country. Moreover, as sodium imposes health risks, determining the sodium content of food products should be a regulation in food industries. In the Islamic Republic of Iran, salt levels in non-industrial processed foods are much higher than in industrial processed foods, which suggests that people should be encouraged to consume industrial food products.

An unhealthy diet is one of the risk factors that can influence the public health of a country (6). Diet has more effect on the health of people of all ages than other factors including physical inactivity, excessive use of

\begin{tabular}{|c|c|c|c|}
\hline \multirow[t]{2}{*}{ Food product } & \multicolumn{2}{|c|}{ Mean (SD) salt content, g/100 g } & \multirow{2}{*}{$\begin{array}{l}\text { Iranian national salt targets, } \\
\qquad \mathrm{g} / 100 \mathrm{~g}^{\mathrm{a}}\end{array}$} \\
\hline & 2016 & 2018 & \\
\hline Canned vegetables & $1.10(0.48)$ & $1.2(0.4)$ & 1.905 \\
\hline Industrial pickled vegetables & $2.36(1.11)$ & $2.4(0.77)$ & 4.000 \\
\hline Non-industrial pickled vegetables & $2.38(0.96)$ & $3.2(1.07)$ & 4.000 \\
\hline Industrial tomato paste/tomato sauce & $2.05(1.33)$ & $1.78(0.37)$ & $1.500 / 2.000$ \\
\hline Non-industrial tomato paste/tomato sauce & Not monitored & $2.37(1.03)$ & $1.500 / 2.000$ \\
\hline Industrial nuts & $0.80(0.45)$ & $1.97(1.31)$ & 1.884 \\
\hline Non-industrial nuts & $1.77(1.73)$ & $2.16(2.08)$ & 1.884 \\
\hline Non-industrial barberry juice (g/100 mL) & $0.27(0.24)$ & $0.79(0.49)$ & 0.250 \\
\hline
\end{tabular}

SD: standard deviation.

a Iranian national salt targets (9-12).

No significant differences were found between the 2016 and 2018 salt levels for any of the food products $(P>0.05)$. 
the alcoholic products and smoking (13). Indeed, health organizations in the Islamic Republic of Iran, headed by the Iranian Ministry of Health and Medical Education, are trying to decrease these health risk factors (13,14). Salt is an important factor for controlling body function, but excessive salt intake leads to noncommunicable diseases (15). WHO recommends consuming $2000 \mathrm{mg}(2 \mathrm{~g})$ of sodium a day and the American Heart Association advises a much lower intake of sodium (1.5 g) a day $(16,17)$.

One way to reduce the salt content of food products is a gradual reduction of salt in each food product. Gradual reduction of salt in industrial and non-industrial food products, and distributing foods with lower salt content can decrease the salt intake in society and improve public health (18). A study in 2003 showed that a gradual decrease in salt in bread of $30 \%$ over 6 weeks did not affect the acceptability of the bread for consumers (19). As a gradual reduction in salt content of food products is a time-consuming process, food producers have looked for other ways to reduce sodium in food products (20). For example, using potassium chloride can produce low-sodium products. In addition to reducing sodium intake, potassium chloride also lowers blood pressure (21). Replacement of sodium chloride with potassium chloride is limited as the high concentrations of potassium chloride results in a metallic, bitter taste in the product (22). Arginine is also a salt taste enhancer. This amino acid provides more than twice as much salty taste as sodium chloride. The combination of arginine and aspartate can increase the salinity of a food product (23).

Between $70 \%$ and $95 \%$ of the salt present in a food enters the body without contact with the taste buds and cannot create a salty taste when swallowed. Normally, the sodium in a food must be dissolved to create a salty taste.
In addition, there is a direct relationship between the rate of dissolving of the salt crystals and the sensation of the salty taste. By reducing the size of the salt crystal, the effective surface area of the crystal increases, and salt size and morphology have been shown to be important factors in the intensity of the salty taste (22). By reducing the size of the salt crystal, the salty taste sensation process is faster and the intensity of the saltiness is also higher. Furthermore, crystals with pyramid, flat and clumped morphologies create more salinity than regular cubed crystals. Therefore, it is possible to reduce the amount of salt consumption in food products, and hence reduce the harmful effects of salt on public health in society, by producing salts with different structures. It is also possible to increase the salinity by using aromatic compounds. The mechanism of action of this phenomenon is not well known. However, research has shown that areas of the brain that cause taste in the mouth are stimulated and activated by flavourings and aromas $(22,24,25)$.

The Iranian national standard salt targets are higher than the WHO recommended level. Indeed, revisions are required to decrease the Iranian standard salt target. Moreover, the Iranian national standard only measures the salt content in foods, but it is better to determine a permitted sodium level and measure its content in food products. This is an important measure in food production for improving the public health.

In addition to regulation to control the level of salt/ sodium in food and therefore in people's diet, consumers' lifestyles should be modified to lower their salt intake and decrease their risk of noncommunicable diseases. Further studies are needed to assess the effect of salt reduction on consumer acceptance.

\section{Acknowledgement}

We thank the Iranian Food and Drug Administration, Shahid Beheshti University of Medical Sciences, and National Nutrition and Food Technology Research Institute.

Funding: None.

Competing interests: None declared.

\section{Teneur en sel des aliments transformés en République islamique d'Iran et respect des normes relatives au sel \\ Résumé}

Contexte: L'Organisation mondiale de la Santé recommande un apport quotidien maximal en sel de $5 \mathrm{~g}$ pour les adultes, et la République islamique d'Iran a établi des normes nationales pour la teneur en sel des aliments.

Objectifs : La présente étude visait à déterminer la teneur en sel des aliments industriels (fabriqués par de grandes entreprises alimentaires) et des aliments artisanaux (fabriqués dans des magasins locaux selon des méthodes traditionnelles) dans la province de Téhéran et à la comparer aux normes nationales iraniennes.

Méthodes: Nous avons déterminé la teneur en sel de 555 produits industriels et artisanaux provenant de diverses régions de la province de Téhéran en 2016 et 2018. Les types d'aliments examinés étaient les suivants : légumes en conserve, pickles industriels et artisanaux, coulis de tomate/sauce tomate industriels et artisanaux, noix industrielles et artisanales et jus d'épine-vinette artisanal. La teneur en sel de chaque produit et sa conformité aux normes nationales iraniennes ont été évaluées. 
Résultats: La teneur en sel des coulis de tomate/sauce tomate industriels en 2016 (2,05 g/100 g), coulis de tomate/sauce tomate artisanaux en 2018 (2,37 g/100 g) était supérieure à la norme iranienne (1,5/2,0 g/100 g). La teneur moyenne en sel des noix industrielles (1,97 g/100 g) et noix artisanales (2,16 g/100 g) était supérieure à la norme iranienne $(1,88 \mathrm{~g} / 100 \mathrm{~g})$, tout comme la teneur moyenne en sel du jus artisanal (0,79 g/100 ml contre $0,25 \mathrm{~g} / 100 \mathrm{ml})$. En 2018, seulement $48 \%$ et $40 \%$ des coulis/sauce tomate industriels et artisanaux étaient conformes à la norme iranienne. Dans l'ensemble, les produits industriels répondaient mieux à la norme nationale que les produits artisanaux.

Conclusions: Des efforts sont nécessaires pour réduire la teneur en sel des aliments transformés en République islamique d'Iran et s'assurer qu'ils sont conformes aux normes iraniennes.

$$
\begin{aligned}
& \text { محتوى الملح في الأغذية المصنعة في جمهورية إيران الإسلامية، والامتثال لمعايير الملح } \\
& \text { فاطمة زنديبودي، سارة سوهر ابوندي، إلهام خانيري، بار انج نيكمرام، روزيتا ـ فانود، كيانوش خسروي، أمير مرتاز افيان، محمد جوليان، نسيم } \\
& \text { خورشيديان } \\
& \text { الخالاصة } \\
& \text { الخلفية: توصي منظمة الصحة العالمية بألا يتجاوز الحد الأقصى من مدخول الملح } 5 \text { جرامات للمات للبالغين يوميًا، وتضع جمهورية إيران الإسلامية معايير } \\
& \text { وطنية لمحتوى الملاح في الأغذية. }
\end{aligned}
$$

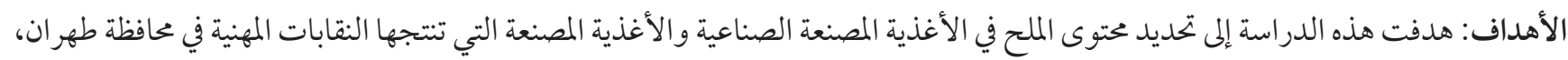

$$
\begin{aligned}
& \text { ومقارنته بالمعايير الوطنية الإيرافية. } \\
& \text { طرق البحث: حددنا محتوى الملح في } 55 \text { منتجًا صناعيًا ونقابيًا من أنحاء مختلفة في محافظة طهران. وشملت أنواع أنقاع الأغذية التي تم فحصها: }
\end{aligned}
$$

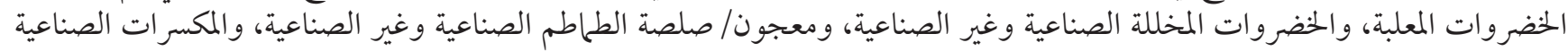

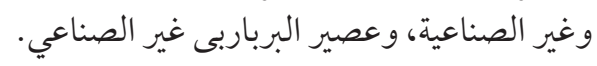

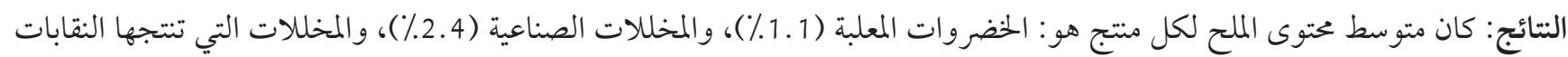

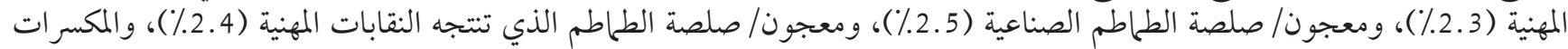

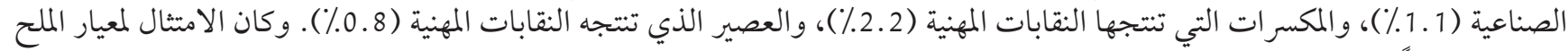

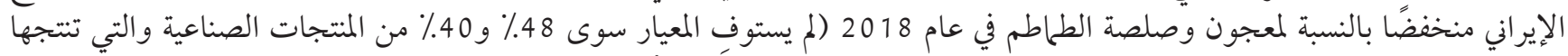

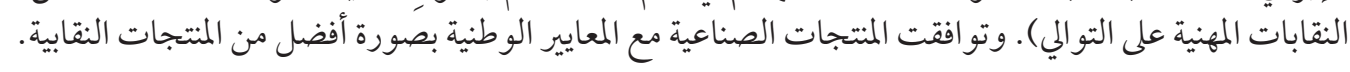

$$
\begin{aligned}
& \text { الاستنتاجات: يلزم بذل جهود للحدّ من محتوى الملح في الأغذية المصنعة في جمهورية إيران الإسلامية وضمان استيفائها للمعايير الإيرانية. }
\end{aligned}
$$

\section{References}

1. Monteiro CA, Levy R B, Claro RM, de Castro IRR, Cannon G. Increasing consumption of ultra-processed foods and likely impact on human health: evidence from Brazil. Public Health Nutrition. 2010;14(1):5-13. https://doi.org/10.1017/S1368980010003241

2. Cappuccio FP. Cardiovascular and other effects of salt consumption. Kidney Int Suppl (2011). 2013;3(4):312-5. https://doi. org/10.1038/kisup.2013.65

3. He FJ, Li J, MacGregor GA. Effect of longer term modest salt reduction on blood pressure: Cochrane systematic review and meta-analysis of randomised trials. BMJ. 2013;4:325-46. https://doi.org/10.1002/14651858.CDo04937.pub2

4. Doyle ME, Glass KA. Sodium reduction and its effect on food safety, food quality, and human health. Compr Rev Food Sci Food Saf. 2010;9(1):44-56. https://doi.org/10.1111/j.1541-4337.2009.00096.x

5. Reducing salt intake in populations: report of a WHO forum and technical meeting, 5-7 October 2006, Paris, France. Geneva: World Health Organization; 2007 (https://www.who.int/dietphysicalactivity/Salt_Report_VC_aprilo7.pdf, accessed 19 February 2021).

6. Man CMD. Technological functions of salt in food products. In: Kilcast D, Angus F, editors. Reducing salt in foods. Cambridge: Woodhead Publishing; 2007:157-73. https://doi.org/10.1533/9781845693046.2.157

7. Khoshtinat K, Beigmohammadi Z, Komeili Fanood R, Abedi A, Kazemzadeh M, Zand Rajabi H, et al. Monitoring risk factors in industrial and non-industrial fried products of the country. Iran J Nutr Sci Food Technol. 2019;14(3):97-108 (in Farsi).

8. Albarracín W, Sánchez IC, Grau R, Barat JM. Salt in food processing; usage and reduction: a review. Int J Food Sci Technol. 2011;46(7):1329-36. https://doi.org/10.1111/j.1365-2621.2010.02492.x

9. [Meat and meat products - determination of chloride content - part 1: Volhard method.] Tehran: Institute of Standards and Industrial Research of Iran; 2008 (In Farsi). 
10. [Canned mixed vegetable - specifications and test methods.] Tehran: Institute of Standards and Industrial Research of Iran; 2013 (in Persian).

11. [Roasted melon seed - specification and test method.] Tehran: Institute of Standards and Industrial Research of Iran; 2017 (in Farsi).

12. [Roasted sunflower seed - specification and test method.] Tehran: Institute of Standards and Industrial Research of Iran; 2017 (in Farsi).

13. [Traditional breads - specifications and test methods.] Tehran: Institute of Standards and Industrial Research of Iran; 2016 (in Farsi).

14. Global action plan for the prevention and control of noncommunicable diseases. Geneva: World health Organization; 2013 (https://www.who.int/publications/i/item/9789241506236, accessed 14 March 2021).

15. Peykari N, Hashemi H, Dinarvand R, Haji-Aghajani M, Malekzadeh R, Sadrolsadat A, et al. National action plan for non-communicable diseases prevention and control in Iran; a response to emerging epidemic. J Diabetes Metab Disord. 2017;16(1):3. https:// doi.org/10.1186/s40200-017-0288-4

16. Whelton PK, Appel LJ, Sacco RL, Anderson CA, Antman EM, Campbell N, et al. Sodium, blood pressure, and cardiovascular disease: further evidence supporting the American Heart Association sodium reduction recommendations. Circulation. 2012;126(24):2880-9. https://doi.org/10.1161/CIR.obo13e318279acbf

17. Salt reduction and iodine fortification strategies in public health: report of a joint technical meeting. Geneva: World Health Organization; 2014 (https://applications.who.int/sites/SHIClaims/SitePages/default.aspx, accessed 14 March 2021).

18. Dötsch M, Busch J, Batenburg M, Liem G, Tareilus E, Mueller R, et al. Strategies to reduce sodium consumption: a food industry perspective. Crit Rev Food Sci Nutr. 2009;49(10):841-51. https://doi.org/10.1080/10408390903044297

19. Girgis S, Neal B, Prescott J, Prendergast J, Dumbrell S, Turner C, et al. One-quarter reduction in the salt content of bread can be made without detection. Eur J Clin Nutr. 2003;57(4):616. https://doi.org/10.1038/sj.ejcn.1601583

20. Binia A, Jaeger J, Hu Y, Singh A, Zimmermann D. Daily potassium intake and sodium-to-potassium ratio in the reduction of blood pressure: a meta-analysis of randomized controlled trials. J Hypertens. 2015;33(8):1509-20. https://doi.org/10.1097/ HJH.0000000000000611

21. Breslin P, Beauchamp G. Salt enhances flavour by suppressing bitterness. Nature. 1997;387(6633):563. https://doi. org/10.1038/42388

22. Lawrence G, Salles C, Septier C, Busch J, Thomas-Danguin T. Odour-taste interactions: a way to enhance saltiness in low-salt content solutions. Food Qual Prefer. 2009;20(3):241-8. https://doi.org/10.1016/j.foodres.2015.07.004

23. Quilaqueo M, Duizer L, Aguilera JM. The morphology of salt crystals affects the perception of saltiness. Food Res Int. 2015;76:675-81. https://doi.org/10.1111/j.1750-3841.2011.02198.x

24. Batenburg M, Van der Velden R. Saltiness enhancement by savory aroma compounds. J food Sci. 2011;76(5):S280-8. https://doi. org/10.1016/j.foodqual.2008.10.004F25.

25. Salles C. Odour-taste interactions in flavour perception. In: Voilley A, Etiévant P, editors. Flavour in food. Cambridge: Woodhead Publishing; 2006. 